\title{
A Indústria Calçadista no Âmbito das Cadeias Produtivas Globais
}

\author{
Aline Correia de Sousa Colantuono ${ }^{1}$ \\ Naina Correia de Sousa ${ }^{2}$
}

\begin{abstract}
Resumo
A globalização industrial tem propiciado grandes mudanças em todo o mundo. O sistema produtivo e o comércio integraram-se, e as nações se especializaram em diferentes ramificações da manufatura. Entre os anos 1970 e 1990, o Brasil, a Coréia do Sul e Taiwan eram os principais produtores e exportadores de calçados do mundo em desenvolvimento. Com o aumento do custo salarial dos países asiáticos, decorrente do avanço de seus processos de industrialização, as vendas externas deles foram superadas pelas exportações de outras economias, tais como: China, Indonésia e Vietnã. Para compreender a lógica desses movimentos, usou-se da pesquisa explicativa, bibliográfica e qualitativa, a fim analisar a reestruturação e a deslocalização da indústria calçadista mundial, por meio do estudo das cadeias produtivas globais.
\end{abstract}

Palavras-chave: Indústria Calçadista. Externalização da Manufatura. Concorrência Mundial.

\section{Footwear Industry in the Context of Global Production Chains}

\begin{abstract}
The industrial globalization has stimulated great changes in the whole world. The productive system and the commerce had been integrated, and the nations had been specialized in different ramifications of the manufacture. Between years 1970 and 1990, Brazil, South Korea and Taiwan were the main footwear's producers and exporters of the underdeveloped world. Because of the wage's increase on Asian countries, resulting from their processes of industrialization, the Koreans and Taiwanese's exportations had been overcome by the exportations of other Asian economies, such as: China, Indonesia and Vietnam. To understand these movements, we used the explanatory literature and qualitative research in order to analyze the reorganization and the outsourcing of world-wide shoe industry, by means of the study of global commodities chains.
\end{abstract}

Keywords: Shoe Industry. Outsourcing. World-Wide Competition.

\section{Introdução}

O rápido avanço na internacionalização das grandes empresas, nas últimas décadas, foi possível tanto pelo desenvolvimento dos meios de transporte e de comunicação, como pelas

\footnotetext{
${ }^{1}$ Economista, mestre em economia pela FCLAR/Unesp e doutoranda em desenvolvimento econômico pelo CEDE/Unicamp. Professora de economia e de fundamentos de economia, na Fatec Ipiranga, nos cursos de gestão comercial e eventos, e de economia, no curso de comércio exterior, na Fatec São Caetano do Sul. alinecsousa@yahoo.com.br

${ }^{2}$ Graduada em Comunicação Social (com ênfase em Publicidade e Propaganda) e especialista em Marketing Estratégico pelo Uni-FACEF; Especialista em Planejamento, Implementação e Gestão da Ead pela UFF; Instrutora de Cursos Gerenciais e Supervisora de Vendas Externas na Embracon Administradora de Consórcio Ltda.nainanina@yahoo.com.br
} 
liberalizações e desregulamentações econômicas. O sistema produtivo e o comércio integraram-se, e as nações se especializaram em diferentes ramos da manufatura. A tendência à externalização dos estágios de produção dos setores tradicionais - tais como vestuário e calçados - foi uma estratégia adotada para reduzir os custos, sobretudo os salários, pois essas indústrias são bastante intensivas em mão de obra.

No final dos anos 1960, a manufatura do calçado foi transferida para o Brasil, a Coréia do Sul e Taiwan, posto que, além de já possuírem capacidade produtiva instalada, desfrutavam de mão de obra a baixo custo. Nos anos 1980, os países do Leste e Sudeste da Ásia, que contavam com disponibilidade de oferta de trabalho mais barata, destacaram-se no mercado mundial de calçados, alterando a dinâmica competitiva desse mercado.

Este artigo tem como objetivo compreender os movimentos de reestruturação e de deslocalização da indústria calçadista mundial, por meio da análise das cadeias produtivas globais. Embora o foco deste trabalho seja a indústria do calçado, empregou-se o exemplo da deslocação da produção da indústria do vestuário para efeito de comparação. Assim, na primeira seção, será abordada a estratégia de produção e de distribuição das firmas produtoras de artigos do vestuário e, na segunda, será apresentada a dissociação entre as atividades de confecção e comercialização da indústria calçadista.

\section{Configurações Produtivas Globais e Externalização da Manufatura como Estratégia Competitiva}

Ao longo do século $\mathrm{XX}$, a grande empresa acumulou recursos produtivos $\mathrm{e}$ mercadológicos, tecnologias e marcas e construiu acesso privilegiado a matérias-primas, conhecimentos e recursos financeiros. Ao mesmo tempo, desenvolveu recursos humanos para promover a expansão internacional e a conquista de mercados importantes no exterior. "[...] Uma razão fundamental para que isto pudesse ocorrer assim está ligada à emergência da dimensão competitividade colocada num plano superior - global” (FURTADO, 2000, p.10).

Nos anos 1970, a entrada de novos competidores internacionais (especialmente asiáticos) no mercado elevou a capacidade de produção, o que acirrou sobremaneira a concorrência. A moderna empresa industrial oligopólica se baseava, cada vez mais, na busca por maior competência em produção, distribuição e diferenciação de produtos.

O rápido avanço na internacionalização das grandes empresas, nas últimas décadas, foi possível tanto pelo desenvolvimento dos meios de transporte e de comunicação, como pelas liberalizações e desregulamentações econômicas. O sistema produtivo e o comércio 
integraram-se, e as nações aumentaram a sua especialização em diferentes ramos da manufatura, ou em alguns estágios da produção.

A internacionalização da economia mundial se tornou mais intensa a partir da década de 1970, momento em que as mudanças engendradas por esse processo permitiram a reformulação das estratégias de produção e distribuição das firmas e a formação de grandes redes corporativas (DUPAS, 2000).

Para compreender o conceito de cadeias globais de produção e os seus desdobramentos, no próximo tópico, serão apresentadas as características, as dimensões e os principais agentes da cadeia de valor do segmento de vestuário.

\subsection{Cadeias de valores comandadas pelos produtores e pelos compradores}

Para Prochnik (2002, p.1), “[...] cadeia produtiva é um conjunto de etapas consecutivas pelas quais passam e vão sendo transformados e transferidos os diversos insumos". Ela “[...] resulta da crescente divisão do trabalho e maior interdependência entre os agentes econômicos". Enquanto as cadeias produtivas

[...] são pensadas como sendo espacialmente localizadas e fortemente coordenadas nesse âmbito (mesmo quando voltadas para mercados que são cada vez mais amplos e externos, e nesse sentido ditos globais), as cadeias produtivas globais são concebidas a partir da noção de que pelo menos alguns dos elementos importantes do seu funcionamento estão deslocalizados, um fato que ocorre mesmo quando o mercado é preponderantemente local (FURTADO, 2000, p.9).

De acordo com Gereffi (1994), a cadeia global de valor tem três dimensões: (I) a estrutura input-output, (II) a territorialidade e (III) a estrutura de governança. A primeira é representada por um conjunto de produtos e serviços ligado a uma seqüência de atividades econômicas que adiciona valor ao mesmo. A segunda ocorre por meio da dispersão espacial, ou através da concentração da produção e das redes de distribuição constituídas por empresas de diferentes tipos e portes. A última incide no interior das relações de autoridade e poder que determinam como os recursos financeiros, materiais e humanos serão alocados.

Duas estruturas de governança distintas surgiram nas últimas décadas: producerdriven commodity chains (cadeias de valores comandadas pelos produtores) e buyer-driven commodity chains (cadeias de valores comandadas pelos compradores). A primeira cadeia é comandada por uma empresa transnacional (ETN) que tem a propriedade do sistema produtivo e dos ativos tecnológicos. A principal característica dessas firmas é a intensidade de capital e de tecnologia que lhes permite controlar toda a rede de fornecedores. Essa estrutura 
de governança é localizada nas indústrias automobilísticas, de computadores, aviões e eletrônica. Por sua vez, as cadeias de valores comandadas pelos compradores são encontradas nas indústrias (de bens de consumo e trabalho-intensivas) em que os varejistas, os comerciantes de "marca" e as trading companies têm como papel fundamental coordenar as redes descentralizadas de produção estabelecidas nos países exportadores emergentes. As indústrias do vestuário, calçados, brinquedos, móveis, utilidades domésticas e outras são exemplos dessa classificação. O quadro 1.1 apresenta as principais características dessas cadeias.

Quadro 1-1 Principais características das cadeias de valores comandadas pelos produtores e pelos compradores

\begin{tabular}{l|l|l}
\multicolumn{1}{c|}{ Características } & \multicolumn{1}{c|}{$\begin{array}{c}\text { Cadeias Comandadas pelos } \\
\text { Produtores }\end{array}$} & \multicolumn{1}{c}{$\begin{array}{c}\text { Cadeias Comandadas pelos } \\
\text { Compradores }\end{array}$} \\
\hline Condutores das Cadeias Globais & Capital industrial & Capital comercial \\
\hline Competências Centrais & P\&D e produção & Design e marketing \\
\hline Barreiras à Entrada & Economias de escala & Economias de escopo \\
\hline $\begin{array}{l}\text { Setores Econômicos } \\
\text { Bentermediários e bens de capital }\end{array}$ & Bens de consumo não duráveis \\
\hline $\begin{array}{l}\text { Indústrias Típicas } \\
\text { Propriedade das Empresas }\end{array}$ & $\begin{array}{l}\text { Automobilística, computadores e } \\
\text { aviação }\end{array}$ & Vestuário, calçados e brinquedos \\
\hline $\begin{array}{l}\text { Principais Vínculos das Redes } \\
\text { Corporativas }\end{array}$ & Empresas transnacionais & $\begin{array}{l}\text { Empresas locais, principalmente de } \\
\text { países em desenvolvimento }\end{array}$ \\
\hline $\begin{array}{l}\text { Estrutura Dominante das Redes } \\
\text { Corporativas }\end{array}$ & Baseados em investimento & Baseados no comércio \\
\hline
\end{tabular}

Fonte: Extraída de Gereffi $(1999$, p.9)

Enquanto as cadeias de valores dirigidas pelos produtores têm a sua competitividade derivada das economias de escala (produção em massa) e dos avanços tecnológicos, as cadeias dirigidas pelos compradores são mantidas através da introdução de novos materiais ao processo produtivo e da constante atualização do design e das funções mercadológicas. Estas exigem a eficiência necessária para a aplicação do modelo de produção baseado na especialização flexível.

Os agentes econômicos pertencentes às cadeias conduzidas pelos compradores são: varejistas, traders, compradores estrangeiros e fabricantes. Os varejistas estabelecem relações com os importadores, ou com as manufaturas do exterior, com o intuito de comercializar os artigos comprados para os seus estabelecimentos, e variam entre lojas de departamento e varejistas especializados em produtos de marca. Os traders são agentes intermediários entre os varejistas e as firmas manufatureiras contratadas e especialistas em importações e/ou indústrias específicas (normalmente, produtos da moda e indústrias de bens de consumo). Os 
compradores estrangeiros têm a mesma função que os traders, todavia, fazem intermediações, em grandes volumes de artigos populares e padronizados, diretamente com as fábricas. Os fabricantes são os responsáveis pela elaboração dos bens envolvidos no contrato de manufatura. Na figura 1.1, encontram-se as relações entre esses agentes.

Figura 1-1 A organização das cadeias de valores comandadas pelos produtores e pelos compradores

1) Cadeias de Valores Comandadas pelos Frodutores

(industrias automobilisticas, de computadores, de avióes e eletrônicas)

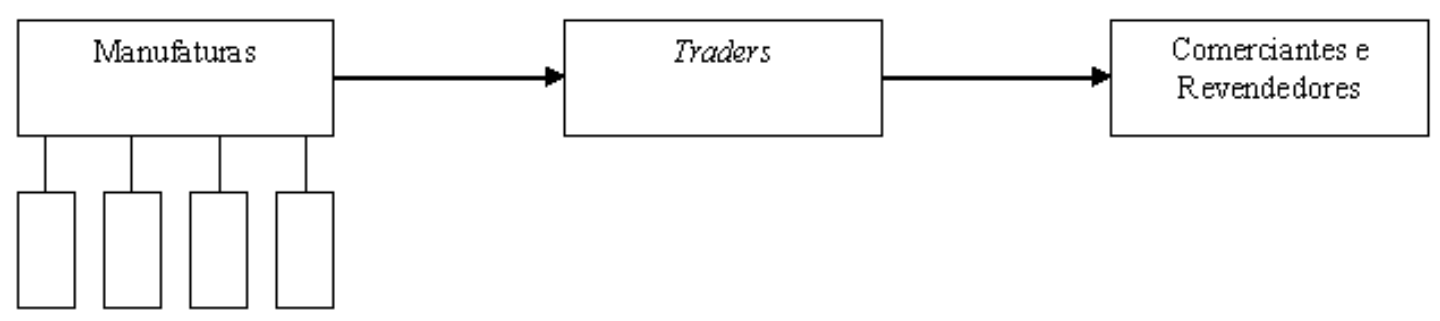

Subsidiarias e Subcontratadas

Domésticas e Estrangeiras

2) Cadeias de Valores Comandadas pelos Compradores

(industrias do vestuánio, calçados, brinquedos, móneis e utilidades domésticas)

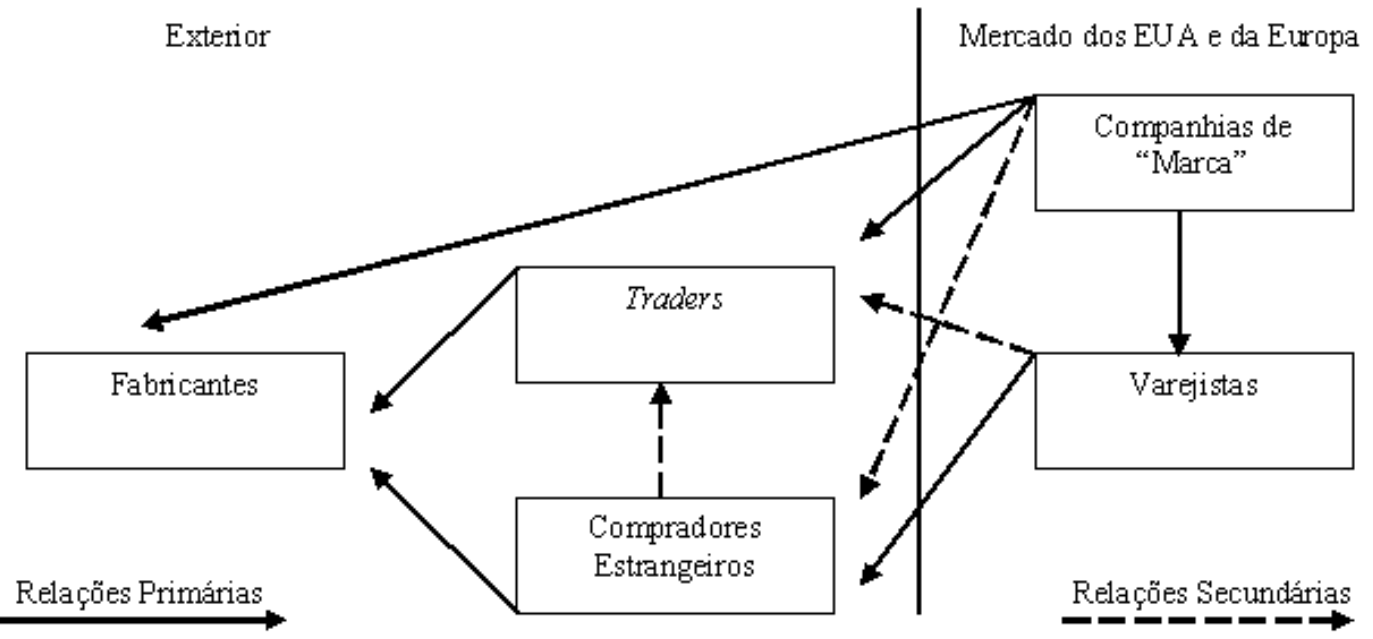

Fonte: Adaptada de Gereffi (1994, p.98).

Uma das principais características das firmas pertencentes às cadeias de valores conduzidas pelos compradores é que a produção, freqüentemente, não faz parte dos seus negócios. Empresas calçadistas e do vestuário, tais como: Nike, Reebok, L. A. Gear, The Limited, The Gap e Liz Claiborne não são consideradas como manufatureiras, porque não possuem fábricas. De forma diversa, essas companhias são consideradas merchandisers, por 
terem se especializado nas atividades de design e marketing dos produtos de marca que vendem (GEREFFI, 1994).

A configuração produtiva global das indústrias têxteis e do vestuário, descrita por Gereffi (1994), é similar à cadeia global de calçados. Ela é dividida em duas dimensões: (I) produtores (fios, tecidos e roupas) e (II) segmentos (padronizados e da moda). Enquanto as corporações transnacionais (TNCs) americanas de fios e tecidos são grandes e intensivas em capital, as fábricas de roupas são fragmentadas, pequenas e intensivas em trabalho. A busca por salários mais baixos e pela flexibilidade organizacional determina a localização geográfica das segundas.

Quanto à orientação dessas empresas, nota-se a existência de grandes companhias estadunidenses de peças do vestuário (jeans, roupa íntima masculina e feminina, entre outras) que se dedicam à produção em massa, tais como: Levi Strauss, VF Corporation e Fruit of the Loom, que tendem a se localizar próximas aos fornecedores dos Estados Unidos, bem como a confeccionar artigos para esse mercado. Somente algumas partes da costura são feitas fora do país. Por sua vez, o segmento da moda abrange os produtores de roupas que têm suas confecções modificadas conforme as estações de compra. A Liz Claiborne, por exemplo, desenvolve seis ou mais coleções por ano. Como empresas semelhantes a essa são voláteis e intensivas em mão-de-obra, normalmente, utilizam o trabalho de fábricas estrangeiras para obter flexibilidade organizacional e desfrutar de salários mais baixos pagos pelas últimas. No quadro 1.2 anexo, encontram-se as diversas modalidades de varejistas e a fonte global dos produtos que comercializam.

As empresas orientadas pela moda atendem a uma clientela exclusiva que exige artigos caros, de marca, com design arrojado e qualidade superior. Esses produtos são originários da Itália, França, Japão e vendidos pelas grifes (Armani, Polo, Gucci e outras) dos Estados Unidos. As lojas de departamento, os magazines especializados e as companhias de marca (Macy's, The Gap, Calvin Klein, entre outras) dão ênfase às "etiquetas privadas" e às marcas nacionais, cuja fonte global se encontra nos países recentemente industrializados (NICs) do Leste Asiático, Brasil, México, Índia, China e outros.

Os comércios de massa vendem produtos de boa qualidade, de preço médio, e originários de exportadores, tais como: NICs, China, Tailândia, Malásia, Filipinas e Indonésia. As grandes cadeias de desconto ofertam produtos baratos com a marca da loja. A fonte de oferta das mesmas (China; Indonésia; Bangladesh; Sri Lanka; Ilhas Maurício; República Dominicana, Guatemala, entre outras) é especializada em artigos de massa produzidos a um custo baixo. Os pequenos importadores atuam como "escoteiros industriais" 
na margem da fronteira internacional de produção a fim de ajudar a encontrar novas fontes potenciais de oferta para a cadeia global de valores (Vietnã, Maynmar, Saipan e outras).

\section{Reestruturação Produtiva da Indústria Calçadista no Mundo e Dissociação entre as Atividades de Confecção e Comercialização}

Apesar das transformações tecnológicas e organizacionais, introduzidas no processo produtivo das empresas para a obtenção de ganhos de produtividade, para a redução dos custos e para o aumento da flexibilidade e aprimoramento da qualidade, a localização da produção de calçados continua condicionada por regiões, ou países que ofereçam salários baixos, visto que algumas etapas desse processo permanecem fortemente artesanais e intensivas em trabalho. $\mathrm{O}$ deslocamento geográfico desse ramo de atividade recomeça sempre que se esgota a capacidade de proporcionar condições competitivas nas regiões calçadistas, ou quando surgem outras nações que disponham de uma força de trabalho ainda mais barata.

Para compreender as alterações dos países no ranking mundial, bem como os movimentos geográficos da indústria do calçado, em face da intensificação da concorrência com novos produtores, é necessário conhecer as etapas de seu processo produtivo e a estrutura de suas empresas.

\subsection{O processo de produção e a estrutura industrial}

A cadeia produtiva coureiro-calçadista abrange um conjunto de atividades de apoio que é determinado pelos efeitos para trás e para frente.

\footnotetext{
Os efeitos para trás constituem-se nas inter-relações que ocorrem respectivamente com indústrias fornecedoras de insumos e demais serviços necessários para o processo de produção, enquanto os efeitos para a frente são relacionados às indústrias de distribuição e reparação do produto acabado (KON, 1994, p.171-2).
}

O processo de fabricação de calçados apresenta duas etapas principais: na primeira, obtêm-se a extração, o curtimento e o acabamento do couro, o qual, por sua vez, é destinado não só à indústria calçadista, como também a outras indústrias, tais como: a moveleira, a do vestuário e a automotiva. Na segunda, ocorre a fabricação do calçado que envolve desde o corte do couro até a embalagem do produto acabado (GARCIA; MADEIRA, 2008).

Além de o calçado ser um produto sujeito às variações da moda, do clima e do gosto dos consumidores, a sua demanda é sensível às variações no nível de atividade econômica e 
no perfil de distribuição de renda. Ademais, esse artigo não só é confeccionado em diversos materiais (couro, tecidos, materiais sintéticos e outros), como atende a muitas finalidades de consumo (social, esportivo, casual, de segurança, entre outros) e se destina a diferentes compradores (homens, mulheres e crianças) (COSTA, 1993; 2002b).

De acordo com Viana e Rocha (2006), o sapato constitui-se em aproximadamente vinte e cinco partes, das quais, o cabedal (parte superior) e o solado (parte inferior) são as mais importantes. Enquanto o cabedal protege o peito do pé e os dedos, o solado se interpõe entre a sola do pé e o chão, a fim de proporcionar equilíbrio ao calçado.

Além disso, esse produto pode ser enriquecido com outros componentes, tais como: contraforte; palmilha; biqueiras; tacões; saltos; almas de aço; calcalhadeiras; cadarços: liqueta entre outros, dependentes do design, da utilização e do processo produtivo requeridos.

A fabricação de calçados é dividida em seis etapas: design, modelagem, corte, costura, montagem e acabamento. Como o fluxo de produção é descontínuo, e as operações são bastante variadas (similar à indústria do vestuário discutida anteriormente), a mecanização do processo torna-se difícil. A figura 2.1 ilustra a sequência dos estágios produtivos da indústria calçadista.

Mesmo que as etapas produtivas sejam exatamente as mesmas para toda a indústria calçadista, a produção pode variar muito de uma empresa para outra, visto que pode ser aperfeiçoada, ou especializada conforme o porte da firma e o nicho de mercado que se pretende atingir. A heterogeneidade da indústria do calçado não apenas possibilita às companhias operarem em mercados e segmentos específicos, como permite que se especializem nos mais diversos estágios da produção. Podem, inclusive, tornar-se fornecedoras de outras empresas do setor (PROCHNIK et al., 2005). No quadro 2.1 anexo, observam-se a estrutura industrial e as características das quatro principais classes de produtores e exportadores de calçados.

O primeiro grupo é representado pela França que, diante dos elevados custos de produção e da intensificação da concorrência com novos produtores mundiais, especialmente asiáticos, adotou como estratégia o reposicionamento no mercado calçadista, ao se especializar em artigos de moda e de luxo, com enfoque na criação e em marketing. Ainda, há empresas de pequeno e médio porte que produzem calçados em algumas regiões francesas (Cholet e Romans), mas a maior parte da produção foi transferida para outros países europeus (Espanha, Hungria, Itália e Portugal) e africanos (Marrocos e Tunísia).

Figura 2-1 Fluxograma do processo de produção de calçados 


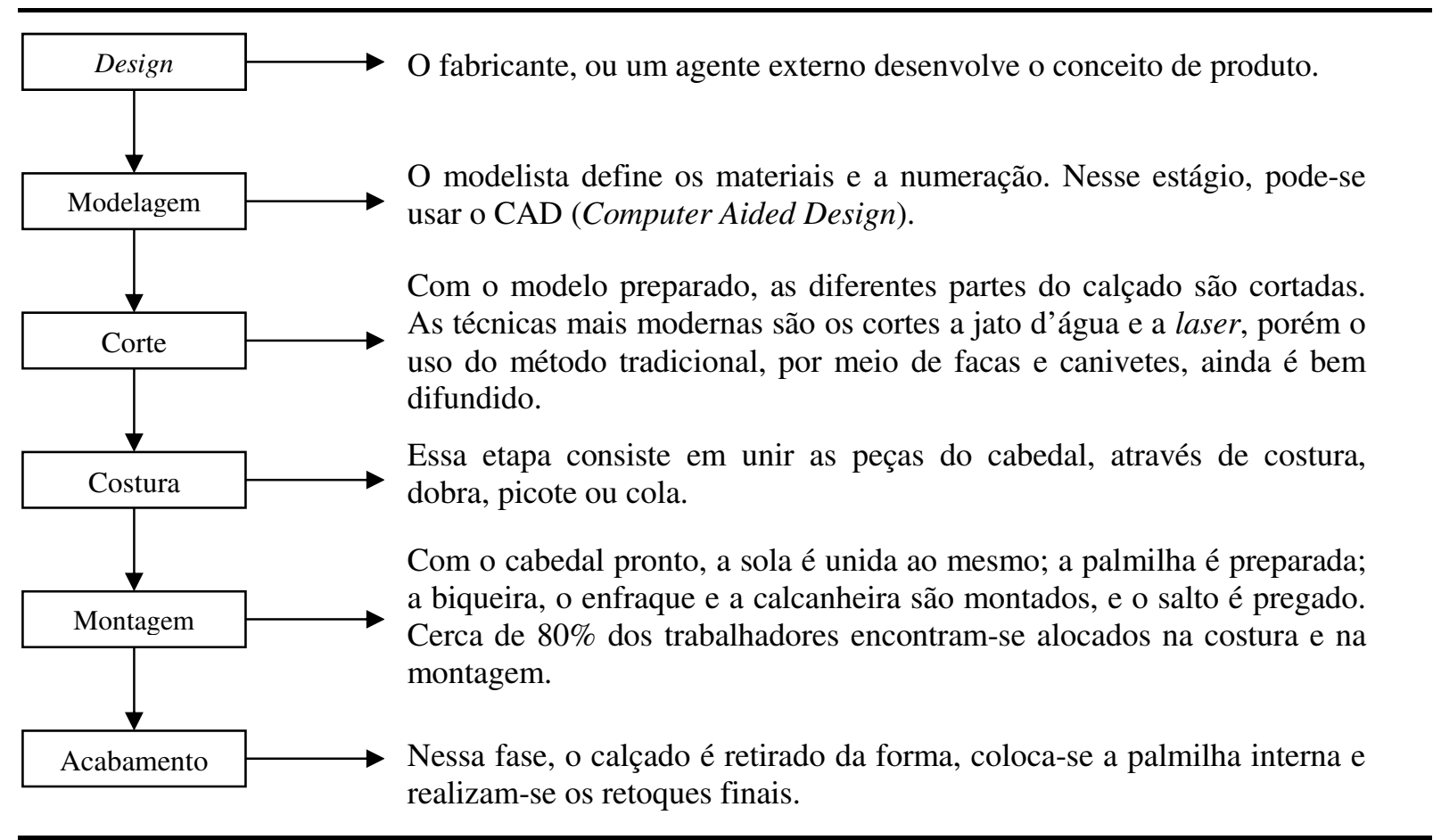

Fonte: Adaptada de Costa (1993) e Prochnik et al. (2005).

A Espanha e a Itália classificaram-se no segundo grupo. Além de se dedicar à criação de modelos e de tendências, esses países continuam a fabricar em pequenas e médias firmas aglomeradas em várias províncias, contudo, o produto italiano ainda é reconhecido internacionalmente pela vantagem Made in Italy. Em razão dos custos, a terceirização da produção se tornou inevitável: Marrocos, Romênia e Tunísia se constituem nas principais fontes globais das economias do Sul da Europa.

A terceira classe é representada por alguns dos países industrializados mais importantes do mundo em desenvolvimento: Taiwan, Brasil e México. Mesmo que a indústria calçadista de Taiwan tenha perdido participação significativa no comércio global, devido ao aumento do custo de produção e à maior especialização em produtos diferenciados e de base científica (artigos eletrônicos), a Pou Chen Company, subcontratada da Nike, continua a elaborar os protótipos em seu território e a deslocar a manufatura para a China. Por sua vez, tanto no Brasil como no México, a confecção de calçados se concentra em empresas de todos os portes espalhadas em vários sistemas locais. A produção desses países não só é voltada para o consumo doméstico, mas também se direciona para o mercado externo. As firmas que se dedicam ao comércio internacional são subcontratadas, normalmente, por grandes distribuidores, em particular, os norte-americanos.

Finalmente, a China, a Índia e a Indonésia classificaram-se no quarto grupo. Além de grandes produtores, são reconhecidos pelo tamanho de seus mercados internos. No entanto, 
uma parte significativa da produção chinesa e indonésia é destinada à exportação, enquanto os indianos consomem, praticamente, tudo o que produzem. A imposição de cotas de importação aos produtos asiáticos, especialmente, aos chineses, fez com que os fabricantes da China e da Indonésia também transferissem alguns estágios produtivos para outras economias da Ásia, entre elas, a Tailândia e o Vietnã, a fim de evitar barreiras ao comércio.

Embora os principais calçadistas mundiais apresentem diferenças estruturais expressivas, todos têm em comum, a propensão de se organizar em densas aglomerações. Assim,

\footnotetext{
No que se refere à localização, são verificados nessas indústrias elementos contraditórios e complementares. Por um lado, a simplicidade da base técnica de produção, aliado à reduzida importância das economias de escala no nível da firma, especialmente nos segmentos de vestuário e de calçados, favorece a formação de sistemas locais de produção. Por outro lado, percebe-se um forte movimento de relocalização [...] onde as empresas conseguem encontrar [...] menores custos do trabalho (GARCIA, 2008, p.4).
}

A partir das informações apresentadas, verificou-se, com nitidez, que o mercado mundial de calçados é bastante segmentado. Conforme Garcia (2001), a indústria calçadista italiana atua no segmento voltado para a inovação, design, diferenciação de produto e preço elevado, enquanto a Índia destaca-se pela especialização em calçados baratos. Contudo, ao mesmo tempo em que a primeira é apoiada pela alta flexibilidade no atendimento de pequenos lotes e pela qualidade dos bens que elabora; a segunda sustenta-se pela escala de produção mais elevada. Embora a China também se dedique à elaboração de calçados baratos, ela se sobressai frente à Índia por vender produtos com qualidade superior, por ser pontual na entrega e por ter capacidade de atender a grandes lotes de encomendas. Já os atributos da indústria calçadista brasileira são: qualidade, alta flexibilidade, tanto em pedidos maiores quanto em menores, e preço intermediário. A figura 2.2 apresenta a segmentação da oferta internacional de calçados.

Figura 2.2 Representação da segmentação da oferta internacional de calçados

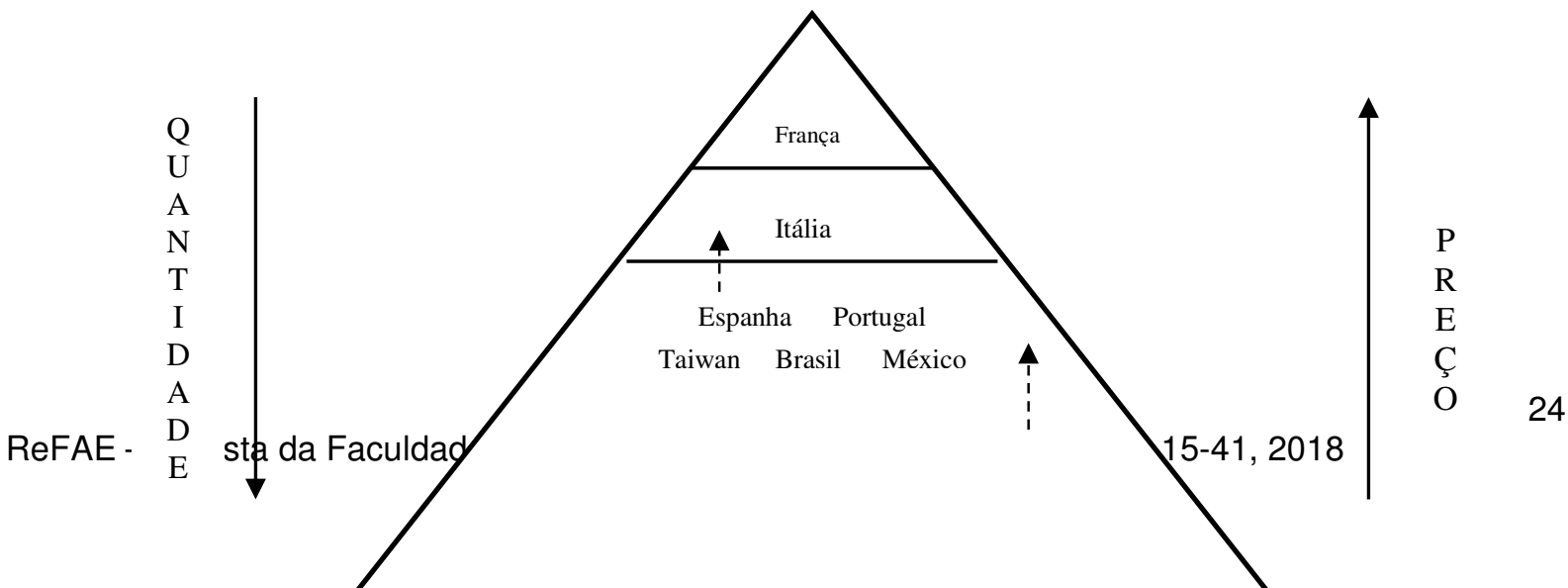




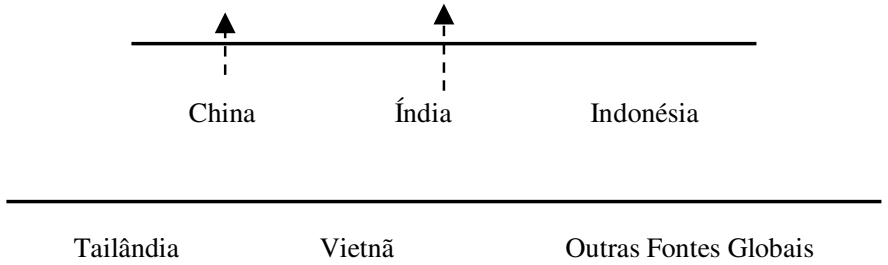

Fonte: Elaboração própria a partir de Garcia (2001, p.151).

Para maiores informações sobre o mercado calçadista mundial, o próximo tópico apresenta não somente as alterações no ranking dos principais países produtores, exportadores, importadores e consumidores, verificadas nos anos 1997, 2005 e 2012, como também os movimentos geográficos da manufatura do calçado, desde 1965 até recentemente.

\subsection{Ranking dos países produtores, exportadores, importadores e consumidores de calçados}

Os maiores exportadores mundiais de calçados não são, necessariamente, os maiores produtores. Como a cadeia global de produção desse bem de consumo é bastante segmentada, alguns integrantes dela se dedicam à confecção, enquanto outros se especializam na distribuição e na comercialização.

A crescente descentralização da produção calçadista foi motivada pelo aumento do custo do trabalho e da concorrência com novos produtores mundiais. Alguns países deixaram de produzir, para se especializar no comércio varejista, entre eles, os Estados Unidos e o Japão; outras economias, como a Coréia do Sul e Hong Kong, passaram a atuar como traders, ao invés de se dedicar à confecção (MORCEIRO, 2008b). Por sua vez, o Brasil, o México, a China, a Índia, a Indonésia, a Tailândia, o Vietnã e outros se especializaram na elaboração de calçados, enquanto a França se concentrou nas atividades de criação e marketing. A Espanha e, principalmente, a Itália ganharam destaque não apenas na criação de modelos e de tendências, como na fabricação de produtos de qualidade.

A figura 2.3 ilustra os principais movimentos de ganho e de perda de market share no comércio internacional de calçados no período recente. Os países que tiveram participação relativa igual ou superior a 1\%, no total das exportações mundiais, estão representados em um dos cinco anéis. As setas sinalizadas para dentro indicam ganho de market share, enquanto as sinalizadas para fora indicam perda. 
Figura 2-3 Mudanças estruturais das exportações mundiais de calçados

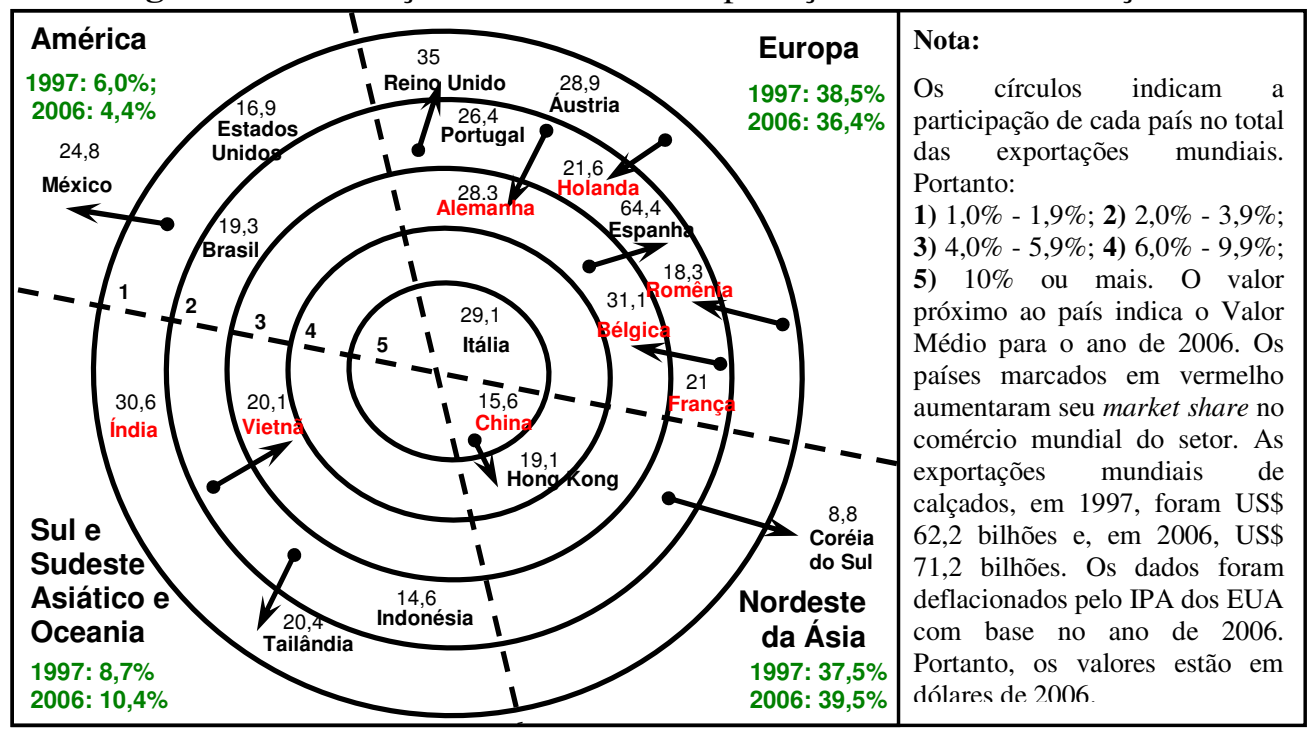

Fonte: Extraída de Morceiro (2008b, p.6).

Tanto a América, como a Europa tiveram a importância relativa reduzida no mercado calçadista mundial, devido à alteração nas posições do Brasil, do México e da Espanha, enquanto a Ásia se destacou em face do bom desempenho da China e do Vietnã. Por sua vez, como Hong Kong se tornou um agente intermediário na cadeia global de calçados, as suas exportações são explicadas pelo volume de sapatos que importa.

As mudanças ocorridas na classificação dos principais países produtores, exportadores, importadores e consumidores, no ranking mundial, para os anos 1997, 2005 e 2012, podem ser observadas nas tabelas 2.1 a 2.4 .

Entre os anos 1970 e 1990, o Brasil, a Coréia do Sul e Taiwan eram os principais produtores e exportadores de calçados do mundo em desenvolvimento. Com o aumento do custo salarial dos países asiáticos, decorrente do avanço de seus processos de industrialização, as vendas externas deles foram superadas pelas exportações de outras economias, tais como: China, Indonésia e Vietnã (LOWDER, 1999).

Na década de 1990, a Ásia consolidou-se como o maior provedor mundial de calçados, visto que, parte importante da capacidade produtiva dessa indústria está localizada nesse continente. Da mesma forma, a China aprofundou sua posição no setor, ao se tornar grande fornecedora global: em 2012, produziu quase 13 bilhões de pares, o que correspondia a $60,5 \%$, da produção mundial em volume.

Tabela 2-1 Ranking dos países produtores de calçados: 1997, 2005 e 2012

\begin{tabular}{|c|c|c|c|c|c|c|c|c|c|}
\hline & \multicolumn{3}{|c|}{1997} & \multicolumn{3}{|c|}{2005} & \multicolumn{3}{|c|}{2012} \\
\hline $\mathrm{N}^{\circ}$ & Países & $\begin{array}{r}\text { Milhões de } \\
\text { pares }\end{array}$ & $\%$ & Países & $\begin{array}{r}\text { Milhões de } \\
\text { pares }\end{array}$ & $\%$ & Países & $\begin{array}{r}\text { Milhões de } \\
\text { pares }\end{array}$ & $\%$ \\
\hline
\end{tabular}




\begin{tabular}{r|lrr|lrr|lrr}
\hline 1 & China & $5.252,00$ & 47,95 & China & $9.000,00$ & 61,95 & China & $12.887,00$ & 60,50 \\
2 & Índia & 680,00 & 6,21 & Índia & 909,00 & 6,26 & Índia & $2.209,00$ & 10,37 \\
3 & Indonésia & 527,20 & 4,81 & Brasil & 762,00 & 5,25 & Brasil & 819,00 & 3,85 \\
4 & Brasil & 520,00 & 4,75 & Indonésia & 580,00 & 3,99 & Vietnã & 804,00 & 3,77 \\
5 & Itália & 460,00 & 4,20 & Vietnã & 525,00 & 3,61 & Indonésia & 700,00 & 3,29 \\
6 & Tailândia & 276,00 & 2,52 & Tailândia & 264,00 & 1,82 & Paquistão & 298,00 & 1,40 \\
7 & Turquia & 270,00 & 2,46 & Paquistão & 251,00 & 1,73 & Bangladesh & 276,00 & 1,30 \\
8 & México & 260,00 & 2,37 & Itália & 250,20 & 1,72 & México & 253,00 & 1,19 \\
9 & Espanha & 207,50 & 1,89 & México & 197,00 & 1,36 & Tailândia & 244,00 & 1,15 \\
10 & Vietnã & 206,00 & 1,88 & Turquia & 170,00 & 1,17 & Itália & 207,00 & 0,97 \\
11 & Outros & $2.296,00$ & 20,96 & Outros & $1.618,40$ & 11,14 & Outros & $2.603,00$ & 12,22 \\
\hline & Total & $10.954,70$ & 100,00 & Total & $14.526,60$ & 100,00 & Total & $21.300,00$ & 100,00 \\
\hline
\end{tabular}

Fonte: Elaboração própria a partir das Resenhas Estatísticas da Abicalçados e do World Footwear (2012).

Após a China, a Índia é o segundo maior produtor de calçados do mundo. Contudo, esses dois países se diferenciam por dois motivos principais: (I) o volume de produção chinês é quase 6 vezes maior que o indiano; (II) 78,9\% da produção chinesa é destinada para o mercado externo, enquanto a maior parte dos calçados produzidos pela Índia é consumida no mercado doméstico.

Entre os países da América Latina, o Brasil é o maior produtor de calçados. Em 2012, chegou à terceira posição no ranking mundial, ao atingir 819 milhões de pares. Contudo, deixou de ser um exportador importante, pois, no ranking de 2012, o Brasil não se encontrava mais entre os dez primeiros exportadores do mundo.

Por sua vez, a Indonésia e a Tailândia se dedicam à elaboração de calçados não só para abastecer os seus consumidores internos, como também para cumprir os acordos de subcontratação feitos com outros países asiáticos, especialmente, com a China. O Vietnã, do mesmo modo, constitui-se em uma fonte global muito importante para o mercado chinês.

Além de grandes produtores de calçados, a China, a Índia, o Brasil e a Indonésia se destacam no ranking mundial como consumidores expressivos, devido ao tamanho de seus mercados, embora o consumo per capita desses países ainda seja baixo. Em 2004, a demanda anual de cada chinês, indiano e brasileiro foi de 2,3, 0,7 e 3 pares, em média, respectivamente (SANTOS; DIAS, 2007).

Apesar de o México estar entre os dez principais produtores mundiais, não se classificou entre os maiores exportadores, pois a produção dele, quando não orientada ao mercado interno, restringe-se aos membros do NAFTA (Canadá e Estados Unidos).

Entre 1997 e 2012, China e Hong Kong destacaram-se como os principais exportadores de calçados do mundo. Em 2012, as duas economias foram responsáveis por mais de $3 / 4$ das vendas de sapatos ao exterior, porém, a China consolidou-se como a maior provedora global desse artigo, enquanto Hong Kong não se classificou entre os dez maiores produtores mundiais, por ter se tornado um trader na cadeia calçadista global. 
Tabela 2-2 Ranking dos países exportadores de calçados: 1997, 2005 e 2012

\begin{tabular}{r|lrr|lrr|lrr}
\hline $\mathrm{N}^{\mathbf{0}}$ & Países & $\begin{array}{r}\text { Milhões } \\
\text { de pares }\end{array}$ & $\%$ & Países & $\begin{array}{r}\text { Milhões de } \\
\text { pares }\end{array}$ & $\%$ & Países & $\begin{array}{r}\text { Milhões } \\
\text { de pares }\end{array}$ & $\begin{array}{r}\% \\
\hline 1\end{array}$ \\
\hline & China & $2.996,00$ & 47,00 & China & $6.914,00$ & 67,72 & China & $10.170,00$ & 73,10 \\
2 & Hong Kong & $1.258,60$ & 19,74 & Hong Kong & 740,60 & 7,25 & Hong Kong & 362,00 & 2,60 \\
3 & Itália & 414,70 & 6,50 & Vietnã & 472,70 & 4,63 & Vietnã & 316,00 & 2,27 \\
4 & Indonésia & 226,80 & 3,56 & Itália & 249,00 & 2,44 & Itália & 229,00 & 1,65 \\
5 & Vietnã & 176,10 & 2,76 & Brasil & 217,00 & 2,13 & Bélgica & 207,00 & 1,49 \\
6 & Tailândia & 156,70 & 2,46 & Indonésia & 165,00 & 1,62 & Indonésia & 206,00 & 1,48 \\
7 & Espanha & 152,60 & 2,39 & Tailândia & 143,00 & 1,40 & Alemanha & 194,00 & 1,39 \\
8 & Brasil & 142,00 & 2,23 & Alemanha & 141,80 & 1,39 & Holanda & 143,00 & 1,03 \\
9 & Portugal & 93,20 & 1,46 & Espanha & 96,40 & 0,94 & Tailândia & 141,00 & 1,01 \\
10 & Taiwan & 62,20 & 0,98 & Holanda & 85,00 & 0,83 & Espanha & 130,00 & 0,93 \\
11 & Outros & 696,00 & 10,92 & Outros & 985,00 & 9,65 & Outros & $1.814,45$ & 13,04 \\
\hline & Total & $6.374,90$ & 100,00 & Total & $10.209,50$ & 100,00 & Total & $13.912,45$ & 100,00 \\
\hline
\end{tabular}

Fonte: Elaboração própria a partir das Resenhas Estatísticas da Abicalçados e do World Footwear (2012).

Enquanto Hong Kong passou a atuar como agente intermediário, ao importar calçados de alguns países produtores (China e Vietnã) e exportá-los para outras economias consumidoras (Estados Unidos e Japão), Taiwan continuou a elaborar tênis, notadamente, para a Nike. Contudo, a participação das empresas taiwanesas, no comércio exterior, reduziuse de modo expressivo, pois, desde 1997 não se encontra mais entre os dez principais exportadores do mundo (ASSINTECAL, 2006i).

A Itália conseguiu se manter entre os três maiores exportadores de calçados, até 2001. Com o aumento da participação da indústria vietnamita no comércio externo, esse país desceu para a quarta posição no ranking mundial. Todavia, "[...] a Itália detém a supremacia exportando produtos de maior "sofisticação" [...]" (MORCEIRO, 2008b, p.8).

Conforme Scott (2006), o Vietnã emergiu como um grande exportador de calçados em 2004, pois foi beneficiado pelas sucessivas transferências de corporações multinacionais de calçados atléticos das regiões que apresentaram aumento de seus níveis salariais, tais como: Coréia do Sul, Taiwan e, mais recentemente, China.

Os dados apresentados nas tabelas 2.1 e 2.2 corroboram a afirmação sobre a consolidação do continente asiático como o maior produtor e exportador de calçados do mundo. Por um lado, em 2012, a Ásia atingiu a marca de 17,418 bilhões de pares, aproximadamente, em um total de 21,3 bilhões de pares produzidos globalmente; por outro, entre os cinco principais países exportadores verificados no ranking mundial, três eram asiáticos: China, Hong Kong e Vietnã.

Os Estados Unidos continuam os maiores importadores mundiais de calçados, apesar de sua participação relativa ter se reduzido de 26,4\% para 22,4\% entre os anos 1997 e 2012. 
Os principais países exportadores (China, Brasil, Indonésia, Vietnã e outros) concorrem entre si para conquistar o mercado norte-americano, e quase todos disputam o segmento de calçados de até US\$12,00, o par (PROCHNIK et al, 2005).

O Japão também se encontra em uma posição de destaque, no ranking mundial, como importador e consumidor de calçados, ao atingir, respectivamente, o segundo e o quinto lugar. Assim como os norte-americanos, os japoneses deixaram de produzir para se tornar grandes varejistas na cadeia calçadista global.

Tabela 2-3 Ranking dos países importadores de calçados: 1997, 2005 e 2012

\begin{tabular}{|c|c|c|c|c|c|c|c|c|c|}
\hline & \multicolumn{3}{|c|}{1997} & \multicolumn{3}{|c|}{2005} & \multicolumn{3}{|c|}{2005} \\
\hline $\mathrm{N}^{\mathrm{o}}$ & Países & $\begin{array}{l}\text { Milhões } \\
\text { de pares }\end{array}$ & $\%$ & Países & $\begin{array}{l}\text { Milhões } \\
\text { de pares }\end{array}$ & $\%$ & Países & $\begin{array}{l}\text { Milhões } \\
\text { de pares }\end{array}$ & $\%$ \\
\hline 1 & EUA & $1.462,00$ & 26,37 & EUA & $2.252,00$ & 25,38 & EUA & $2.302,00$ & 22,40 \\
\hline 2 & Hong Kong & $1.297,60$ & 23,40 & Hong Kong & 866,00 & 9,76 & Japão & 619,00 & 6,02 \\
\hline 3 & Japão & 384,30 & 6,93 & Japão & 556,00 & 6,27 & Alemanha & 593,00 & 5,77 \\
\hline 4 & Alemanha & 345,30 & 6,23 & Alemanha & 464,00 & 5,23 & França & 480,00 & 4,67 \\
\hline 5 & Reino Unido & 247,70 & 4,47 & Reino Unido & 424,00 & 4,78 & Reino Unido & 455,00 & 4,43 \\
\hline 6 & França & 245,80 & 4,43 & França & 379,30 & 4,27 & Hong Kong & 425,00 & 4,14 \\
\hline 7 & Itália & 157,50 & 2,84 & Itália & 331,70 & 3,74 & Itália & 358,00 & 3,48 \\
\hline 8 & CEI & 145,00 & 2,61 & Espanha & 247,00 & 2,78 & Espanha & 354,00 & 3,44 \\
\hline 9 & Bélgica & 102,60 & 1,85 & Rússia & 178,00 & 2,00 & Rússia & 256,00 & 2,49 \\
\hline 10 & Holanda & 100,00 & 1,80 & Holanda & 163,50 & 1,84 & Holanda & 245,00 & 2,38 \\
\hline \multirow[t]{2}{*}{11} & Outros & $1.057,40$ & 19,07 & Outros & $3.012,40$ & 33,95 & Outros & $4.189,79$ & 40,77 \\
\hline & Total & $5.545,20$ & 100,00 & Total & $8.873,90$ & 100,00 & Total & $10.276,79$ & 100,00 \\
\hline
\end{tabular}

Fonte: Elaboração própria a partir das Resenhas Estatísticas da Abicalçados e do World Footwear (2012).

Por sua vez, os países europeus (Alemanha, França e Reino Unido) deixaram de ser grandes produtores e exportadores de calçados, para se tornarem importantes importadores e consumidores. Entretanto, a União Europeia impõe fortes restrições tarifárias para dificultar a entrada de calçados fabricados fora desse bloco econômico. "Isto explica, em parte, a maior participação dos fabricantes europeus no seu próprio mercado" (PROCHNIK et al, 2005, p.22).

Os calçados comprados pela Alemanha são originários da Espanha, da Itália, da Hungria, da Polônia, da Romênia e da República Tcheca, enquanto as principais fontes globais da França são a Espanha, a Hungria, a Itália, a Romênia e Portugal. O Reino Unido importa, principalmente, da Espanha, da Hungria, da Polônia, da Romênia e da República Tcheca (ASSINTECAL, 2006a, 2006c, 2006f, 2006g, 2007c, 2008b).

Em suma, enquanto a China, a Índia e o Brasil configuram-se como grandes produtores e consumidores mundiais de calçados, os Estados Unidos, o Japão e as economias da Europa Ocidental apresentam elevado consumo. Como inexiste, praticamente, produção doméstica de calçados nessas últimas nações, pode-se afirmar que a demanda delas está quase que exclusivamente associada às importações. 
Tabela 2-4 Ranking dos países consumidores de calçados: 1997, 2005 e 2012

\begin{tabular}{|c|c|c|c|c|c|c|c|c|c|}
\hline & \multicolumn{3}{|c|}{1997} & \multicolumn{3}{|c|}{2005} & \multicolumn{3}{|c|}{2005} \\
\hline $\mathrm{N}^{\mathrm{o}}$ & Países & $\begin{array}{r}\text { Milhões de } \\
\text { pares }\end{array}$ & $\%$ & Países & $\begin{array}{r}\text { Milhões de } \\
\text { pares }\end{array}$ & $\%$ & Países & $\begin{array}{r}\text { Milhões de } \\
\text { pares }\end{array}$ & $\%$ \\
\hline 1 & China & $2.258,40$ & 22,30 & EUA & $2.241,90$ & 17,00 & China & $2.761,00$ & 15,90 \\
\hline 2 & EUA & $1.622,70$ & 16,03 & China & $2.096,50$ & 15,90 & EUA & $2.248,00$ & 12,95 \\
\hline 3 & Índia & 645,70 & 6,38 & Índia & 852,40 & 6,46 & Índia & $2.202,00$ & 12,68 \\
\hline 4 & Japão & 572,10 & 5,65 & Japão & 650,30 & 4,93 & Brasil & 740,00 & 4,26 \\
\hline 5 & Brasil & 427,00 & 4,22 & Brasil & 555,00 & 4,21 & Japão & 697,00 & 4,01 \\
\hline 6 & Alemanha & 331,40 & 3,27 & Indonésia & 490,00 & 3,71 & Indonésia & 526,00 & 3,03 \\
\hline 7 & França & 325,70 & 3,22 & Reino Unido & 397,00 & 3,01 & Alemanha & 429,00 & 2,47 \\
\hline 8 & Indonésia & 314,00 & 3,10 & França & 369,30 & 2,80 & França & 424,00 & 2,44 \\
\hline 9 & Reino Unido & 297,70 & 2,94 & Alemanha & 351,00 & 2,66 & Reino Unido & 372,00 & 2,14 \\
\hline 10 & México & 242,00 & 2,39 & Itália & 332,90 & 2,52 & Itália & 336,00 & 1,93 \\
\hline 11 & Outros & $3.088,30$ & 30,50 & Outros & $4.854,80$ & 36,80 & Outros & $6.629,78$ & 61,82 \\
\hline & Total & $10.125,00$ & 100,00 & Total & $13.191,10$ & 100,00 & Total & $17.364,78$ & 100,00 \\
\hline
\end{tabular}

Fonte: Elaboração própria a partir das Resenhas Estatísticas da Abicalçados e do World Footwear (2012).

A partir das informações apresentadas, verifica-se, com clareza, a configuração de um padrão mundial da localização da produção de calçados: de um lado, alguns países asiáticos, o Brasil e a Itália constituem-se em importantes fabricantes; de outro, as economias centrais caracterizam-se como grandes demandantes.

[...] As possibilidades de desintegração das etapas do processo de concepção, produção, comercialização e distribuição de calçados permitiram que os grandes compradores globais adotassem estratégias de busca de fontes de suprimento que apresentassem custos mais reduzidos, especialmente aqueles relacionados com a força de trabalho (GARCIA; MADEIRA, 2008, p.16).

Os principais movimentos de deslocalização dos estágios produtivos da indústria calçadista são temas do próximo tópico.

\subsubsection{A transferência geográfica da manufatura}

Até os anos 1970, as exportações de calçados eram efetuadas, em quantidade significativa, pela Alemanha, Áustria, Espanha, França, Itália e pelo Reino Unido. Com o aumento do custo dos trabalhadores empregados na produção desse bem de consumo, a participação dos países europeus no mercado calçadista mundial se reduziu. Na tabela 2.5 , verificam-se essas informações.

Tabela 2-5 Participação das exportações dos países europeus no mercado mundial de calçados (em \%) e custo salarial dos trabalhadores por hora (em US\$ reais de 1975 - EUA): 1975 - 1990

\begin{tabular}{l|rrrr|rrrr}
\hline \multicolumn{1}{c|}{ Países } & \multicolumn{4}{|c|}{ Participação das exportações (em \%) } & \multicolumn{4}{c}{ Custo salarial (em US\$ - EUA) } \\
& 1975 & 1980 & 1985 & 1990 & 1975 & 1980 & 1985 & 1990 \\
\hline Alemanha & 3,8 & 5,1 & 4,3 & 4,1 & 4,5 & 5,7 & 3,5 & 6,3 \\
Áustria & 3,3 & 4,0 & 2,6 & - & - & - & - & -
\end{tabular}




\begin{tabular}{l|rrrr|rrrrr} 
Espanha & 11,0 & 6,7 & 7,4 & 6,2 & - & - & - & 3,3 \\
França & 9,2 & 7,6 & 5,2 & 3,4 & 3,7 & 4,8 & 3,1 & 5,0 \\
Itália & 38,0 & 43,2 & 33,8 & 28,0 & 3,3 & 4,2 & 2,9 & 5,6 \\
Reino Unido & 3,0 & - & - & - & 3,0 & 4,4 & 2,6 & 4,5 \\
\hline
\end{tabular}

Fonte: Adaptada de Costa (1993) e da OIT (1996 apud COSTA, 2002b). Não se encontraram dados salariais disponíveis para a Áustria.

Entre 1975 e 1990, a participação das exportações da França foi a que mais declinou, enquanto a Itália permaneceu como o maior país exportador de calçados da Europa, apesar da queda de 10 pontos percentuais. Quanto ao custo salarial, todas as nações selecionadas apresentaram aumento: o salário pago por hora na Alemanha, na França e no Reino Unido se elevou 39,1\%,35,8\% e 49,7\%, respectivamente, no período. Na Itália, o mesmo aumentou $69,8 \%$, ao passar de US $\$ 3,3$ para US $\$ 5,6$. Por isso, os ramos de atividades intensivos em trabalho vêm experimentando um processo de externalização da manufatura e "[...] a geografia da produção de calçados a partir de 1970 tem sido determinada fortemente por custos de produção, especialmente os relacionados à mão de obra" (COSTA, 2002b, p.2).

A produção das economias avançadas (Estados Unidos, Japão e países do Norte da Europa) se reduziu rapidamente, no final dos anos 1960, enquanto algumas nações (Brasil, Coréia do Sul e Taiwan) se destacaram como grandes produtoras internacionais. Esses últimos países não só possuíam capacidade produtiva e competência técnica para a confecção desse artigo, como desfrutavam de mão de obra a baixo custo. Os pólos nacionais escolhidos para se integrarem a essa cadeia global de produção foram o do Vale do Sinos e o de Franca, por apresentarem maior tradição e competitividade (COSTA, 1993, 2002a, 2002b).

Nos anos 1980, o movimento de deslocalização da produção da indústria calçadista foi norteado para outras regiões em desenvolvimento, tais como: China, Filipinas, Indonésia e Tailândia. Esse fenômeno pode ser explicado pelo avanço do processo de industrialização dos "tigres asiáticos", o qual induziu ao aumento da taxa salarial desses países e ao concomitante progresso das exportações para categorias tecnológicas mais elevadas. No gráfico 2.1, observa-se a evolução do custo da mão de obra das economias do Leste Asiático.

Gráfico 2-1 Custo salarial por hora dos trabalhadores do Leste Asiático alocados na produção de calçados (em US\$ reais de 1975 - EUA): 1975 - 1990 


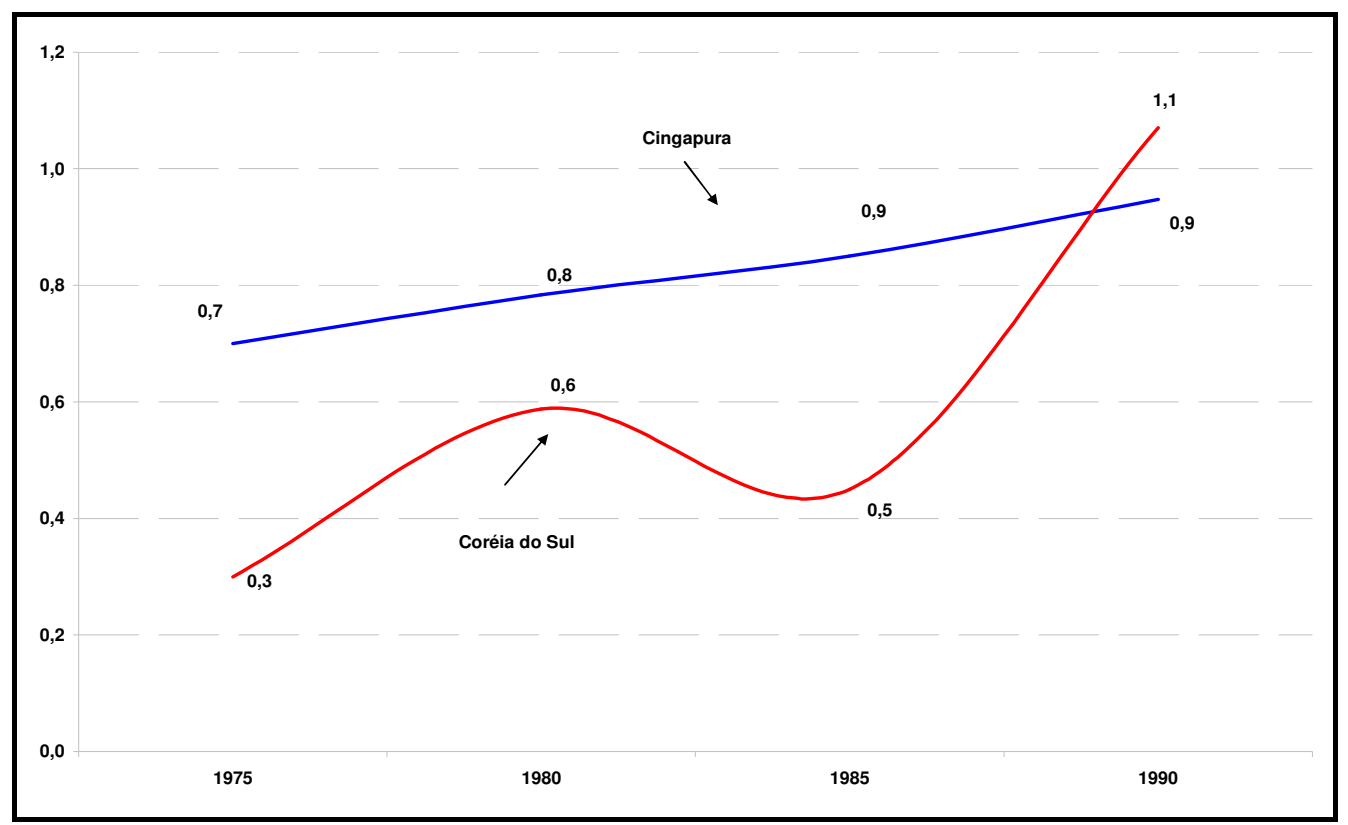

Fonte: Elaboração própria a partir de OIT (1996 apud COSTA, 2002b).

O custo salarial dos trabalhadores empregados na indústria calçadista de Cingapura e da Coréia do Sul cresceu, entre 1975 e 1980, ao configurar aumento de 12\% e 96\%, respectivamente. Em 1985, o salário pago por hora no setor de calçados voltou a crescer na Coréia do Sul, ao atingir US\$1,1 em 1990.

À medida que a internacionalização da produção se intensifica, os agentes tendem a transferir as atividades mais tradicionais (roupas, calçados e móveis) a países menos desenvolvidos (SCOTT, 2006). Além do custo do trabalho, fatores macroeconômicos, culturais e estruturais explicam o desempenho da indústria calçadista nessas nações (LOWDER, 1999).

Além da distribuição geográfica da produção, a configuração dos pedidos das redes varejistas também vem se alterando. Nas décadas de 1970 e 1980, as ordens de compra realizadas pelos compradores estrangeiros nas regiões produtoras eram de até 100 mil pares de sapatos, e o principal importador eram os Estados Unidos. No entanto, verificou-se uma redução no volume de compras, a partir da segunda metade dos anos 1980, período em que ocorreu a inserção de novos países (China, Filipinas, Indonésia, Tailândia e Vietnã) na cadeia de valor da indústria. Nos anos 1990, as encomendas entre 1 mil e 3 mil pares eram muito comuns (COSTA, 1993, 2002b; PROCHNIK et al, 2005).

A tendência à reorganização da cadeia global de produção, de comercialização e de distribuição da indústria calçadista, no mercado mundial, vem sendo acompanhada pelo deslocamento de algumas ramificações da manufatura para lugares onde os custos são mais reduzidos. Os grandes compradores globais não só buscam fontes mais baratas de suprimento, 
como exercem o papel de coordenadores da cadeia, ao comandar os processos produtivos espalhados por todo o mundo (GARCIA; MADEIRA, 2008).

Ao analisar o mercado internacional de calçados, Scott (2006) identificou os três principais fluxos comercias existentes entre os países compradores e as economias produtoras: no primeiro, as TNCs dos Estados Unidos permanecem como as maiores importadoras das firmas que se localizam na Europa (Itália), na Ásia (China e Vietnã) e na América (Brasil). No segundo, os países da Europa Ocidental não só comercializam entre si, como demandam serviços de manufatura das economias do Leste Europeu. No terceiro, Hong Kong se mantém como um importante entreposto da Ásia, apesar de exercer menor domínio, na cadeia produtiva, em relação aos Estados Unidos. A figura 2.5 apresenta esses fluxos.

Figura 2-5 Principais fluxos do comércio bilateral de calçados

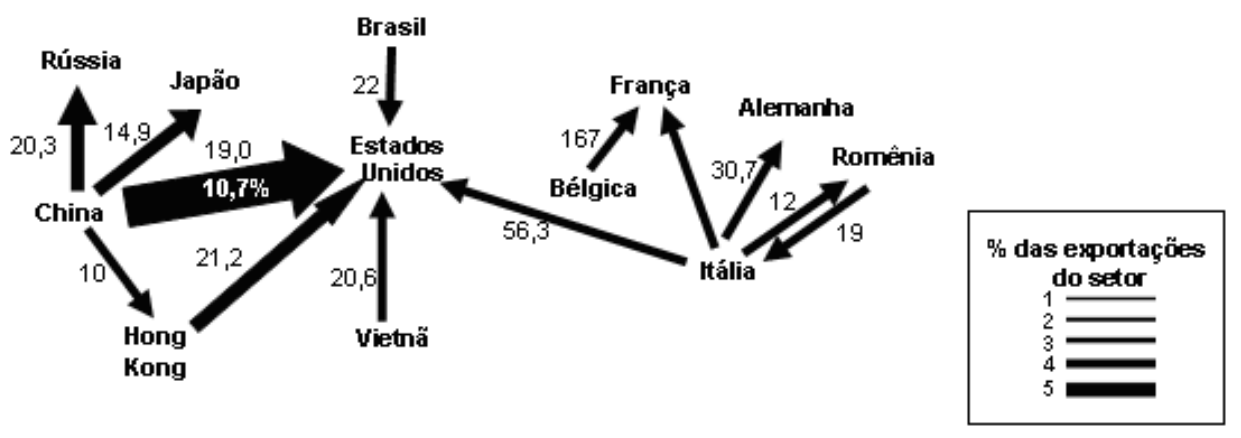

Fonte: Extraída de Morceiro (2008b, p.8).

Nota: A figura mostra apenas os fluxos comerciais que correspondem a mais de $1 \%$ das exportações mundiais. Os números que aparecem próximos às setas representam o Valor médio.

Para se adaptar à nova dinâmica do mercado mundial, as empresas calçadistas dos países produtores passaram por um forte processo de reestruturação. A busca por capacidades inovativas e tecnológicas ganhou importância no setor, já que a produção, crescentemente repassada a terceiros por meio de subcontratação, deixou de ser função estratégica. Dessa forma, a aplicação de novos materiais ao processo produtivo, o desenvolvimento de produto e de design diferenciado, a intensificação da interface eletrônica nas firmas, a normatização do artigo acabado e a organização da cadeia global através das Tecnologias de Informação e Comunicação (TIC) se constituíram nas principais tendências tecnológicas da cadeia de couro, calçados e artefatos (GARCIA; MADEIRA, 2008).

No entanto, mesmo que a intensificação da concorrência estimule as estratégias de relocalização industrial e de reestruturação produtiva, a fim de reduzir os custos de produção e 
de aumentar a competitividade, os APLs (Arranjos Produtivos Locais) ainda são fundamentais para promover a apropriação das externalidades positivas locais (benefícios exógenos à firma, mas endógenos ao sistema). Tanto as firmas de calçados maiores, que têm condições de se deslocar mundialmente, quanto as empresas menores se beneficiam das vantagens exercidas pelos sistemas locais de produção (GARCIA, 2008).

\section{Considerações Finais}

Nos anos 1970, a entrada de novos competidores internacionais (especialmente asiáticos) no mercado elevou a capacidade de produção, o que acirrou sobremaneira a concorrência. A moderna empresa industrial oligopólica se baseava, cada vez mais, na busca por maior competência em produção, distribuição e diferenciação de produtos.

O rápido avanço na internacionalização das grandes empresas, nas últimas décadas, foi possível tanto pelo desenvolvimento dos meios de transporte e de comunicação, como pelas liberalizações e desregulamentações econômicas. O sistema produtivo e o comércio integraram-se, e as nações aumentaram a sua especialização em diferentes ramos da manufatura, ou em alguns estágios da produção (GEREFFI, 1994).

O processo de deslocalização da produção é adotado por muitas empresas com o objetivo de reduzir os custos, sobretudo os salários, uma vez que muitas indústrias são bastante intensivas em mão de obra (vestuário e calçados). Além disso, como o custo do trabalho ainda permanece diferente entre os países, ou mesmo, entre regiões de um mesmo país, a transferência de etapas do processo produtivo a fornecedores especializados torna-se necessária para a promoção da competitividade das empresas.

Mesmo que as etapas produtivas sejam exatamente as mesmas para toda a indústria calçadista, a produção pode variar muito de uma empresa para outra, visto que pode ser aperfeiçoada ou especializada conforme o porte da firma e o nicho de mercado que se pretende atingir. A heterogeneidade da indústria do calçado não apenas possibilita às companhias operarem em mercados e segmentos específicos, mas também permite que se especializem nos mais diversos estágios da produção. Podem, inclusive, tornar-se fornecedoras de outras empresas do setor (PROCHNIK et al, 2005).

Alguns países deixaram de produzir, para se especializar no comércio varejista, como os Estados Unidos e o Japão; outras economias, a Coréia do Sul e Hong Kong, passaram a atuar como traders, ao invés de se dedicar à confecção (MORCEIRO, 2008b). Por sua vez, o Brasil; o México; a China; a Índia; a Indonésia; a Tailândia; o Vietnã e outros se 
especializaram na elaboração de calçados, enquanto a França se concentrou nas atividades de criação e marketing. A Espanha e, principalmente, a Itália ganharam destaque tanto na criação de modelos e de tendências quanto na fabricação de produtos de qualidade.

A tendência à reorganização da cadeia global de produção, de comercialização e de distribuição da indústria calçadista, no mercado mundial, vem sendo acompanhada pelo deslocamento de algumas ramificações da manufatura a lugares onde os custos são mais reduzidos. Os grandes compradores globais não só buscam fontes mais baratas de suprimento, como exercem o papel de coordenadores da cadeia, ao comandar os processos produtivos espalhados por todo o mundo (GARCIA; MADEIRA, 2008).

\section{Referências}

ABICALÇADOS. Estatísticas. Resenhas Estatísticas: 2001 a 2007. Disponível em: $<$ http://www.abicalcados.com.br/estatisticas.html >. Acesso em: 19 mar. 2008.

ANDERSON, P. Barreiras não-tarifárias às exportações brasileiras no MERCOSUL: o caso de calçados. Texto para discussão n.791. Rio de Janeiro: IPEA, 2001.

ANDRADE, J, E. P. CORREAA, A. R. Panorama da indústria mundial de calçados, com ênfase na América Latina. Rio de Janeiro: BNDES Setorial, n.13, p.95-126, mar. 2001.

ASSINTECAL. Estudo de mercado: Espanha - componentes para couro, calçados e artefatos. Novo Hamburgo, p.1-36, 2006a.

ASSINTECAL. Estudo de mercado: Indonésia - componentes para couro, calçados e artefatos. Novo Hamburgo, p.1-29, 2006b.

ASSINTECAL. Estudo de mercado: Itália - componentes para couro, calçados e artefatos, p.1-34. Novo Hamburgo, 2006c.

ASSINTECAL. Estudo de mercado: Marrocos - componentes para couro, calçados e artefatos, p.1-34. Novo Hamburgo, 2006d.

ASSINTECAL. Estudo de mercado: Paquistão - componentes para couro, calçados e artefatos, p.1-34. Novo Hamburgo, 2006e.

ASSINTECAL. Estudo de mercado: Polônia - componentes para couro, calçados e artefatos, p.1-34. Novo Hamburgo, 2006f.

ASSINTECAL. Estudo de mercado: República Tcheca - componentes para couro, calçados e artefatos, p.1-34. Novo Hamburgo, 2006g.

ASSINTECAL. Estudo de mercado: Rússia - componentes para couro, calçados e artefatos, p.1-34. Novo Hamburgo, 2006h. 
ASSINTECAL. Estudo de mercado: Taiwan - componentes para couro, calçados e artefatos, p.1-28. Novo Hamburgo, 2006i.

ASSINTECAL. Estudo de mercado: Tunísia - componentes para couro, calçados e artefatos, p.1-28. Novo Hamburgo, 2006j.

ASSINTECAL. Estudo de mercado: Índia - componentes para couro, calçados e artefatos. Novo Hamburgo, p.1-39, 2007a.

ASSINTECAL. Estudo de mercado: México - componentes para couro, calçados e artefatos. Novo Hamburgo, p.1-32, 2007b.

ASSINTECAL. Estudo de mercado: Hungria - componentes para couro, calçados e artefatos. Novo Hamburgo, p.1-32, 2007c.

ASSINTECAL. Estudo de mercado: China - componentes para couro, calçados e artefatos. Novo Hamburgo, p.1-32, 2008a.

ASSINTECAL. Estudo de mercado: Romênia - componentes para couro, calçados e artefatos. Novo Hamburgo, p.1-32, 2008 b.

COSTA, A. B. Competitividade da indústria de calçados: nota técnica setorial do complexo têxtil. In: COUTINHO, L. G.; FERRAZ, J. C. (Coords.). Estudo da competitividade da indústria brasileira. Campinas: IE/UNICAMP, 1993. Disponível em: <http://www.mct.gov.br/upd_blob/2264.pdf>. Acesso em: fev. 2007.

Organização industrial e competitividade da indústria de calçados brasileira. Análise Econômica, Porto Alegre, ano 19, n.36, p.45-66, set. 2002a.

Nota técnica final cadeia: couro-calçados. In: COUTINHO, L. G. et al.

(Coords.). Estudo da competitividade de cadeias integradas no Brasil: impactos das zonas de livre comércio. Campinas: IE-NEIT/UNICAMP, 2002b.

COUTINHO, L. G.; FERRAZ, J. C. (Org.). Estudo da competitividade da indústria brasileira. Campinas: PAPIRUS/Ed. UNICAMP, 1995. p.95-123.

DRUVOT, H.; MACHADO NETO, A. J. A indústria calçadista francesa diante do seu declínio. FACEF Pesquisa, Franca, v.7, n.3, 2004. p.98-108.

DUPAS, G. Economia global e exclusão social: pobreza, emprego, estado e o futuro do capitalismo. 2.ed. Rio de Janeiro: Paz e Terra, 2000. p.39-86.

FURTADO, J. Limites e possibilidades do Brasil nas configurações produtivas globalizadas: uma análise apoiada em diversas cadeias. Relatório temático apresentado ao IPEA e MDIC. Araraquara: GEEIN, 2000.

GARCIA, R. C. Aglomerações industriais ou distritos industriais: um estudo das indústrias têxteis e de calçados no Brasil. 1996. 151. Dissertação (Mestrado em 'economia'). - Instituto de Economia, UNICAMP, Campinas, 1996. 
Vantagens competitivas de empresas em aglomerações industriais: um estudo aplicado à indústria brasileira de calçados e sua inserção nas cadeias produtivas globais. 2001. 204. Tese (Doutorado em 'economia'). - Instituto de Economia, UNICAMP, Campinas, 2001.

A indústria de calçados e insumos. Rio de Janeiro: FINEP, Relatório DPP. 2006. Disponível em www.finep.gov.br/portaldpp.

. Uma análise do processo de desconcentração regional nas indústrias têxtil e de calçados e a importância dos sistemas locais de produção. In: XIII Encontro Regional de Economia, 2008, Fortaleza. Anais do XIII ANPEC Nordeste, Fortaleza: Banco do Nordeste, 2008.

GARCIA, R.; MADEIRA, P. Uma agenda de competitividade para a indústria paulista: cadeia couro e calçados. IPT, São Paulo, fev. 2008.

GEREFFI, G. Paths of industrialization: an overview. In: GEREFFI, G.; WYMAN, D. L. Manufacturing miracles: paths of industrialization in Latin America and East Asia. New Jersey: Princeton, 1990.

GEREFFI, G. The organization of buyer-driven global commodities chains: how US retailers shape overseas production networks. In: GEREFFI, G.; KORZENIEWIEZ, M. Commodity chains and global capitalism. Londres: Praeger, 1994.

GEREFFI, G. A commodity chains framework for analyzing global industries. Durham: Duke University, 1999. Mimeo. (Forthcoming in American Behavioral Scientist).

KON, Anita. Economia industrial. São Paulo: Nobel, 1994.

LOWDER, S. Globalisation of the footwear industry: a simple case of labour? Tijdschrift voor Economische en Sociale Geografic, v.90, n.1, p.47-60, 1999.

LUPATINI, M. P. As transformações produtivas na indústria têxtil-vestuário e seus impactos sobre a distribuição territorial da produção e a divisão do trabalho industrial. 2004. 168. Dissertação (Mestrado em 'política científica e tecnológica') - Instituto de Geociências, UNICAMP, Campinas, 2004.

MINISTÉRIO DO DESENVOLVIMENTO, INDÚSTRIA E COMÉRCIO EXTERIOR. Indicadores e Estatísticas. Secretaria de Comércio Exterior - SECEX. Disponível em: $<$ http://www2.desenvolvimento.gov.br/sitio/secex/depPlaDesComExterior/indEstatisticas/bal Comercial.php>. Acesso em 2007.

MORCEIRO, P. C. Mudanças recentes na inserção internacional da indústria brasileira: uma análise dos fluxos de comércio dos produtos intensivos em trabalho. 2008. 91. Relatório Final Pibic (Iniciação científica em 'economia'). - Faculdade de Ciência e Letras, UNESP, Araraquara, 2008a.

. Mudanças recentes na inserção internacional da indústria brasileira: uma análise dos fluxos de comércio dos produtos intensivos em trabalho. In: XX CIC - Congresso de Iniciação Científica, 2008, São José dos Campos. Anais do XX CIC, São José dos Campos: UNESP, 2008b. 
OIT. Mundialización de las industrias del calzado, los textiles e el vestido: informe para el debate de la reunión tripartita sobre la incidencia en el empleo y en las condiciones de trabajo de la mundialización de las industrias del calzado, los textiles y el vestido. Ginebra: Organización Internacional del Trabajo, vi, 142 p., 1996.

PROCHNIK, V. Cadeias produtivas e complexos industriais. In: HASENCLEVER, L.; KUPFER, D. Organização industrial. Rio de Janeiro: Campus, 2002. (Seção do capítulo Firma, Indústria e Mercados).

PROCHNIK, V. et al. Perfil do setor de calçados. In: PROCHNIK, V. (Coord.). Relatório final de pesquisa para o SEBRAE. Rio de Janeiro: IE/UFRJ, 2005.

SANTOS, F; DIAS, A. M. Panorâmica da produção e distribuição mundial de calçados. Couromoda, São Paulo, 30 jan. 2007. Notícias. Empresas. Disponível em: $<$ http://www.couromoda.com.br/noticias/empresa/Enoticia_1509.html $>$. Acesso em: nov. 2008 .

SCOTT, A. J. The changing global geography of low-technology, labor-intensive industry: clothing, footwear, and furniture. World Development, v.34, n.9, p.1517-1536, 2006.

VIANA, F. L. E.; ROCHA, R. E. V. A indústria de calçados no Nordeste: características, desafios e oportunidades. Fortaleza: Banco do Nordeste, 2006, p.11-28.

WORLD FOTWEAR: year book 2012. Disponível em: $<$ http://www.portugueseshoes.pt/estatisticas/2012WorldFootwearYearbook.pdf $>$. Acesso em 14 jan. 2014. 
Quadro 1-2 Varejistas dos Estados Unidos e respectivas fontes globais de produtos têxteis e do vestuário

\begin{tabular}{|c|c|c|c|}
\hline $\begin{array}{l}\text { Modalidades de } \\
\text { Varejistas }\end{array}$ & Firmas Representativas & Principais Fontes Globais & $\begin{array}{c}\text { Características dos } \\
\text { Pedidos dos } \\
\text { Compradores }\end{array}$ \\
\hline $\begin{array}{l}\text { Empresas Orientadas pela } \\
\text { Moda }\end{array}$ & $\begin{array}{l}\text { Armani, Donna Karan, } \\
\text { Polo/Ralph Lauren, Hugo } \\
\text { Boss, Gucci }\end{array}$ & $\begin{array}{l}\text { (1) Itália, França, Reino Unido } \\
\text { e Japão; (2) Taiwan, Hong } \\
\text { Kong, Cingapura e Coréia do } \\
\text { Sul. }\end{array}$ & $\begin{array}{l}\text { Produtos caros que } \\
\text { requerem design e altos } \\
\text { níveis de qualidade; os } \\
\text { pedidos são em } \\
\text { pequenos lotes. }\end{array}$ \\
\hline $\begin{array}{l}\text { Lojas de Departamento, } \\
\text { Magazines Especializados } \\
\text { e Companhias de Marca. }\end{array}$ & $\begin{array}{l}\text { Bloomingdale's, Saks } \\
\text { Fifth Avenue, Neiman- } \\
\text { Marcus, Macy's, } \\
\text { Nordstrom, The Gap, The } \\
\text { Limited, Liz Claiborne, } \\
\text { Calvin Klein }\end{array}$ & $\begin{array}{l}\text { (2) Taiwan, Hong Kong, } \\
\text { Cingapura e Coréia do Sul; (3) } \\
\text { Malásia, Indonésia, Filipinas, } \\
\text { China, Índia, Turquia, Egito, } \\
\text { Brasil, México e Tailândia; (4) } \\
\text { Caribe, América Central, } \\
\text { EAU, Marrocos, Tunísia, } \\
\text { China, Bangladesh, Siri } \\
\text { Lanka, Paquistão, Macau, } \\
\text { Saipan, Ilhas Maurício, } \\
\text { Zimbábue, Quênia, Leste } \\
\text { Europeu, Chile e Colômbia. }\end{array}$ & $\begin{array}{lrr}\text { Produtos caros, de alta } \\
\text { qualidade, que são } \\
\text { vendidos } \text { sob uma } \\
\text { variedade de marcas } \\
\text { nacionais e "etiquetas } \\
\text { privadas" } \\
\text { Marca); } \text { (Lojas } & \text { de } \\
\text { tamanho } & \text { médio } & \text { e } \\
\text { grande } & \text { coordenados } \\
\text { pelos grupos } & \text { de } \\
\text { compras das Lojas de } \\
\text { Departamento. }\end{array}$ \\
\hline Comércios de Massa & $\begin{array}{l}\text { Sears Roebuck, J. C. } \\
\text { Penney }\end{array}$ & $\begin{array}{l}\text { (2) Taiwan, Hong Kong, } \\
\text { Cingapura e Coréia do Sul; (3) } \\
\text { Malásia, Indonésia, Filipinas, } \\
\text { China, Índia, Turquia, Egito, } \\
\text { Brasil, México e Tailândia; (4) } \\
\text { Caribe, América Central, } \\
\text { EAU, Marrocos, Tunísia, } \\
\text { China, Bangladesh, Siri } \\
\text { Lanka, Paquistão, Macau, } \\
\text { Saipan, Ilhas Maurício, } \\
\text { Zimbábue, Quênia, Leste } \\
\text { Europeu, Chile e Colômbia. }\end{array}$ & $\begin{array}{l}\text { Produtos de } \\
\text { médio, decço } \\
\text { qualidade, que } \\
\text { preponderantemente, } \\
\text { vendidos sob "etiquetas } \\
\text { privadas"; } \\
\text { grandes. }\end{array}$ \\
\hline Cadeias de Desconto & Wal-Mart, Kmart, Target & $\begin{array}{l}\text { (3) Malásia, Indonésia, } \\
\text { Filipinas, China, Índia, } \\
\text { Turquia, Egito, Brasil, México } \\
\text { e Tailândia; (4) Caribe, } \\
\text { América Central, EAU, } \\
\text { Marrocos, Tunísia, China, } \\
\text { Bangladesh, Siri Lanka, } \\
\text { Paquistão, Macau, Saipan, } \\
\text { Ilhas Maurício, Zimbábue, } \\
\text { Quênia, Leste Europeu, Chile } \\
\text { e Colômbia. (5) Peru, Bolívia, } \\
\text { El Salvador, Nicarágua, } \\
\text { Vietnã, Rússia, Madagascar, } \\
\text { Coréia do Norte, Mayanmar, } \\
\text { Camboja, Laos e Fiji. }\end{array}$ & 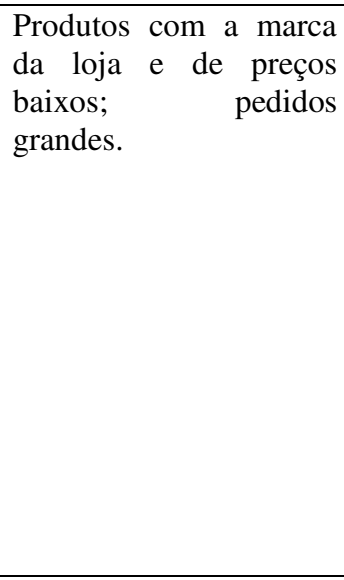 \\
\hline Pequenos Importadores & - & $\begin{array}{l}\text { (4) Caribe, América Central, } \\
\text { EAU, Marrocos, Tunísia, } \\
\text { China, Bangladesh, Siri } \\
\text { Lanka, Paquistão, Macau, } \\
\text { Saipan, Ilhas Maurício, } \\
\text { Zimbábue, Quênia, Leste } \\
\text { Europeu, Chile e Colômbia. } \\
\text { (5) Peru, Bolívia, El Salvador, } \\
\text { Nicarágua, Vietnã, Rússia, } \\
\text { Madagascar, Coréia do Norte, } \\
\text { Mayanmar, Camboja, Laos e } \\
\text { Fiji. }\end{array}$ & $\begin{array}{l}\text { Compras-piloto; atuam } \\
\text { como "escoteiros } \\
\text { industriais" em busca de } \\
\text { novas fontes de oferta; } \\
\text { os pedidos são } \\
\text { relativamente pequenos } \\
\text { em um primeiro } \\
\text { momento, mas têm o } \\
\text { potencial de crescer } \\
\text { rapidamente se os } \\
\text { ofertantes forem de } \\
\text { confiança. }\end{array}$ \\
\hline
\end{tabular}

Fonte: Adaptada de Gereffi (1994). 
Quadro 2-1 Estrutura industrial e características dos principais grupos de países produtores e exportadores de calçados

\begin{tabular}{|c|c|c|c|c|c|}
\hline Países & $\begin{array}{l}\text { Aglomerações } \\
\text { Industriais }\end{array}$ & $\begin{array}{l}\text { Fontes } \\
\text { Globais }\end{array}$ & $\begin{array}{l}\text { Competências } \\
\text { Centrais }\end{array}$ & $\begin{array}{l}\text { Porte das } \\
\text { Empresas }\end{array}$ & Características da Indústria e do Produto \\
\hline França & Cholet e Romans & $\begin{array}{l}\text { Espanha, } \\
\text { Hungria, } \\
\text { Itália, } \\
\text { Marrocos, } \\
\text { Portugal e } \\
\text { Tunísia }\end{array}$ & $\begin{array}{l}\text { Criação e } \\
\text { marketing }\end{array}$ & $\begin{array}{l}\text { Pequeno e } \\
\text { médio }\end{array}$ & $\begin{array}{l}\text { Metade da produção é confeccionada em } \\
\text { couro. Para não sair totalmente do } \\
\text { mercado mundial, em função do aumento } \\
\text { do custo da mão de obra, empresários } \\
\text { franceses apostaram nos artigos de moda e } \\
\text { luxo }\end{array}$ \\
\hline Espanha & $\begin{array}{l}\text { Aragón, Castilla La } \\
\text { Mancha, Ilhas } \\
\text { Baleares, La Rioja, } \\
\text { Murcia e Valencia }\end{array}$ & $\begin{array}{l}\text { Marrocos, } \\
\text { Romênia e } \\
\text { Tunísia }\end{array}$ & $\begin{array}{l}\text { Criação e } \\
\text { produção }\end{array}$ & $\begin{array}{l}\text { Pequeno e } \\
\text { médio }\end{array}$ & $\begin{array}{l}\text { Produtores espanhóis redirecionaram a } \\
\text { estratégia de produção, ao focar no design } \\
\text { diferenciado e de alta qualidade. Os } \\
\text { calçados são elaborados, principalmente, } \\
\text { em couro, seguidos de tecidos e plásticos }\end{array}$ \\
\hline Itália & $\begin{array}{l}\text { Campania, Emília } \\
\text { Romana, } \\
\text { Lombardia, Marche, } \\
\text { Porto Sant'Elpidio, } \\
\text { Puglia, Toscana e } \\
\text { Veneto }\end{array}$ & $\begin{array}{l}\text { Marrocos, } \\
\text { Romênia e } \\
\text { Tunísia }\end{array}$ & $\begin{array}{l}\text { Criação e } \\
\text { produção }\end{array}$ & $\begin{array}{l}\text { Pequeno e } \\
\text { médio }\end{array}$ & $\begin{array}{l}\text { Aproximadamente } 2 / 3 \text { dos calçados são } \\
\text { feitos de couro em empresas cujo ciclo de } \\
\text { produção é completamente automatizado e } \\
\text { moderno. Os símbolos da indústria italiana } \\
\text { são moda, bom gosto, flexibilidade e } \\
\text { inovação }\end{array}$ \\
\hline Taiwan & Taichung & China & Produção & $\begin{array}{l}\text { Pequeno, } \\
\text { médio e } \\
\text { grande }\end{array}$ & $\begin{array}{l}\text { Os calçados são fabricados, } \\
\text { principalmente, em materiais plásticos e } \\
\text { sintéticos (chinelos e sandálias). A Pou } \\
\text { Chen Company, maior fabricante de tênis } \\
\text { do mundo, e subcontratada da Nike, está } \\
\text { em Taiwan }\end{array}$ \\
\hline Brasil & $\begin{array}{l}\text { Birigui, Campina } \\
\text { Grande, Franca, } \\
\text { Jaú, Juazeiro do } \\
\text { Norte, Nova } \\
\text { Serrana, São João } \\
\text { Batista e Vale do } \\
\text { Sinos }\end{array}$ & - & Produção & $\begin{array}{l}\text { Pequeno, } \\
\text { médio e } \\
\text { grande }\end{array}$ & $\begin{array}{l}\text { A indústria brasileira é bastante } \\
\text { heterogênea: as grandes empresas utilizam } \\
\text { processos sofisticados e materiais } \\
\text { plásticos (borracha) e têxteis a fim de } \\
\text { produzir tênis, especialmente, para o } \\
\text { mercado interno. As firmas médias são } \\
\text { especializadas em sapatos de couro natural } \\
\text { voltados ao mercado externo. As pequenas } \\
\text { empresas utilizam processos artesanais } \\
\text { para abastecer o mercado doméstico. }\end{array}$ \\
\hline México & $\begin{array}{l}\text { León, Guadalajara e } \\
\text { Cidade do México }\end{array}$ & - & Produção & $\begin{array}{l}\text { Pequeno, } \\
\text { médio e } \\
\text { grande }\end{array}$ & $\begin{array}{l}\text { Enquanto o design da indústria mexicana } \\
\text { acompanha as tendências internacionais de } \\
\text { moda, com forte influência italiana, a } \\
\text { tecnologia de produção apresenta uma clara } \\
\text { defasagem se comparada à existente no } \\
\text { Brasil e no mundo. Muitas firmas são } \\
\text { subcontratadas de empresas americanas }\end{array}$ \\
\hline China & $\begin{array}{l}\text { Fujian, Guangdong, } \\
\text { Henan, Jiangsu e } \\
\text { Zhejiang }\end{array}$ & $\begin{array}{l}\text { Indonésia, } \\
\text { Tailândia e } \\
\text { Vietnã }\end{array}$ & $\overline{\text { Produção }}$ & $\begin{array}{l}\text { Médio e } \\
\text { grande }\end{array}$ & $\begin{array}{l}\text { Os principais tipos de calçados fabricados } \\
\text { são os de materiais plásticos, têxteis, de } \\
\text { couro e os esportivos. Algumas regiões se } \\
\text { dedicam à confecção de tênis da Adidas, } \\
\text { Nike e Reebok, enquanto outras produzem } \\
\text { com marca própria para o mercado chinês }\end{array}$ \\
\hline Índia & $\begin{array}{l}\text { Agra, Ambur, } \\
\text { Bangalore, Chennai, } \\
\text { Délhi, Jallandhar, } \\
\text { Kanpur, Mumbai e } \\
\text { Ranipet }\end{array}$ & - & Produção & $\begin{array}{l}\text { Pequeno e } \\
\text { médio }\end{array}$ & $\begin{array}{l}\text { A produção indiana distribui-se em } \\
\text { calçados masculinos (64\%), femininos } \\
(20 \%) \text { e infantis (16\%). Os casuais, os } \\
\text { esportivos, os mocassins, as botas e as } \\
\text { sandálias são os principais modelos } \\
\text { confeccionados, especialmente, para o } \\
\text { mercado doméstico }\end{array}$ \\
\hline Indonésia & $\begin{array}{l}\text { Bandung, Jakarta e } \\
\text { Surabaya }\end{array}$ & $\begin{array}{l}\text { China, } \\
\text { Tailândia e } \\
\text { Vietnã }\end{array}$ & Produção & $\begin{array}{l}\text { Pequeno e } \\
\text { médio }\end{array}$ & $\begin{array}{l}\text { Produção caracterizada por preços baixos } \\
\text { e design pouco elaborado. As empresas } \\
\text { familiares da Indonésia se dedicam ao } \\
\text { mercado interno, enquanto as joint- } \\
\text { ventures e as subcontratadas produzem } \\
\text { para grandes marcas mundiais }\end{array}$ \\
\hline
\end{tabular}


Fonte: Elaboração própria a partir de Costa (1993), Anderson (2001), Andrade e Corrêa (2001), Druvot e Machado Neto (2004), Prochnik et al (2005), Scott (2006) e Assintecal (2006a, 2006b, 2006c, 2006d, 2006i, 2006j, 2007a, 2007b, 2007c, 2008a e 2008b). 